\title{
Use of a simulated grazing technique for the evaluation of tropical grasses'
}

\author{
Rafael Ramos and José E. Rodríguez.s
}

\begin{abstract}
The adaptive potential of $\mathbf{2 0}$ forage cultivars was evaluated by using a simulated grazing technique (cutting at 21 - and 28-day intervals during long-day and short-day season, respectively) over a $11 / 2$-year period at Corozal. Most of the 12 Cynodon cultivars were susceptible to fungi during a very rainy period. With the exception of $C$. nlemfuensis PRPI 2341 and C. plectostachyus PRPI 12949, none of the eight Hemarthria altissima cultivars presented this problem. Cynodon cultivars suffered moderate to severe insect damage; $\boldsymbol{H}$. altissima cultivars slight to moderate damage. Eleven Cynodon cultivars presented a poor to medium resistance. Four of the H. altissima cultivars (PRPI 13202 and 13178, and USDAPI 379617 and 364873 ) excelled in terms of dry matter production both seasons in development qualities (plant height and soil cover) and disease as well as insect and weed tolerance. The simulated grazing technique in combination with agronomic evaluation was effective for screening many grass accessions within a short time.
\end{abstract}

\section{RESUMEN}

La simulación de apacentamiento para evaluar yerbas tropicales

Se evaluó el potencial de adaptación de 20 forrajes utilizando la técnica de apacentamiento simulado (corte a intervalos de 21 y 28 días durante épocas de días largos y cortos, respectivamente) durante $11 / 2$ año en Corozal. La mayoría de las 12 cultivares de Cynodon fueron susceptibles al ataque de hongos durante un período altamente lluvioso, a excepción de $C$. nlemfuensis PRPI 2341 y C. plectostachyus PRPI 12949. Ninguna de las ocho cultivares de Hemarthria altissima fue susceptible. Las Cynodon fueron susceptibles a daños por insectos considerados entre moderados y severos y las Hemarthria entre leves y moderados.

Once cultivares de Cynodon demostraron resistencia entre pobre y moderada a la infestación por yerbajos durante los días largos. Las cultivares de $H$. altissima fueron excelentes o buenas en relación a tolerancia a la infestación por yerbajos.

La producción de materia seca de cuatro cultivares de $\boldsymbol{H}$. altissima (PRPI 13202, 13178 y USDAPI 379617 y 364873 ) fue alta en las épocas de días cortos y largos. Además, mostraron excelentes características de desarrollo (altura y cobertura) y tolerancia a insectos, enfermedades y yerbajos.

El uso de la téenica de apacentamiento simulado, combinado con evaluaciones agronómicas, mostró ser un buen método de selección para evaluar el potencial de muchas introducciones de gramíneas en un corto tiempo.

'Manuscript submitted to Editorial Board 11 April 1989.

"Research Assistant, Department of Agronomy.

"Research Technician. Department of Agronomy. 


\section{INTROONUCTION}

An important component of pasture evaluation is the selection of accessions adapted to a particular environment and production system. The lack of comparable results from different experiments is a major problem in grazing studies. For this reason, the evaluation technique of forages should simulate as closely as possible the farming conditions under which the accessions are to be used $(2,5)$. It is difficult to select the best materials from a large number of possible introductions, especially in the first stages (4).

Experiments on small plots under cutting conditions are very useful to compare the suitability of new accessions with those used commercially. Management at different regrowth intervals can simulate grazing frequencies. Another important aspect is the characterization of the adaptive capacity of each variety on the basis of weed, insect and disease resistance (4). However, following this initial stage, further testing using animals is necessary to assess persistence against animal pressure and the related grazing management factors, grazing systems, grazing period and recovery period under rotation grazing $(5,6)$.

Vicente-Chandler et al. (16) reported that heavily fertilized Pangola grass produced higher dry matter yields when grazed down to $15 \mathrm{~cm}$ than when grazed to $5 \mathrm{~cm}$. Similarly, Rodriguez, and Silva (9) found that a grazing height of about 15 to $20 \mathrm{~cm}$ at grazing intervals of 28 days during the short-day season and 21 days during the long-day season was suitable for stargrass in the humid mountain region of Corozal.

In Puerto Rico many agxonomic studies have been reported on Cynodon accessions under cutting conditions. Among the best accessions, Cynodon nlemfuensis PRPI 2341 (Star), C. plectostachyus PRPI 11487 and $C$. dactylon Coastcross-1, have proven to be productive $(11,12,14$, 15). Although these are potentially acceptable $(11,12,14,15)$, only $C$. nlemfuensis PRPI 2341 is currently extensively utilized.

Few studies have been locally performed on the forage production potential of Hemarthria altissima $(8,15)$. Vélez and Arroyo (15) reported that $H$. altissima PRPI 299995 produced higher yields than four other accessions under cutting conditions. A 3-year grazing study by Rivera and Rodríguez (8) showed that $H$. altissima PRPI 299994 was the highest yielder, with a mean forage dry matter production of $15,370 \mathrm{~kg} / \mathrm{ha} /$ year. Studies at the University of Florida showed a high in vitro organic matter digestion (IVOMD) coefficient for the tetraploid Hemarthria accession Bigalta (PRPI 299995). According to Shank et al. (10) the genetic improvement of Hemarthria accessions was considered feasible because of their ability to persist under flooding, drought and freezing temperatures. They also found that IVOMD was significantly higher in coarse stemmed tetraploid lines from Africa than in diploid lines (10). 
The objectives of the experiments herein reported were 1) to compare the adaptive performance and forage production potential of Cynodon and Hemarthria accessions by using a simulated grazing technique; 2) to assess the suitability of the simulated grazing technique for selecting forage accessions in short time intervals; 3 ) to select the best adapted materials for further tests using grazing animals.

\section{MATERIALS AND METHODS}

The experiment was conducted on a Corozal clay soil (Aquic Tropudults). Soil $\mathrm{pH}$ was increased to 5.5 with the application of limestone before planting. Mean annual precipitation was 2,121 $\mathrm{mm}$ and mean daily temperature was $25.10^{\circ} \mathrm{C}$. Twelve Cynodon and eight Hemarthria cultivars were evaluated in an incomplete balanced block design with four replications. Eighty $12.5-\mathrm{m}^{2}$ plots, each with four rows of the same grass, were planted 24 March 1987. After the first 2 months of the 6month establishment period, all plots received $336 \mathrm{~kg} / \mathrm{ha}$ of a 15-5-10 fertilizer. During the first year after the establishment each plot received the same fertilizer at the rate of $2,243 \mathrm{~kg} / \mathrm{ha}$ divided into four applications. Grass in each plot was cut $15 \mathrm{~cm}$ above the ground level every 28 days during the short-day season and every 21 days during the long-day season, to determine the dry matter yield, simulating grazing on a rotation system.

Plant height, covering ability, and disease tolerance were determined during forage establishment. During the 8 th, 12th and 16th weeks after planting, plant height was measured from the ground to the top leaves of six plants randomly selected from every plot. Covering ability was also estimated from a $1-\mathrm{m}^{2}$ quadrat divided in 25 equal squares (13). Thirteen weeks after establishment, coinciding with a rainy period of $1,025 \mathrm{~mm}$, each plot was examined for fungi infestation. A $1-\mathrm{m}^{2}$ quadrat was used to facilitate counting plant population and the percentage of leaves damaged on six plants randomly selected from each plot. The following formula was used for this determination:

$$
\begin{gathered}
\text { Percentage of leaves } \\
\text { damaged } / \mathrm{m}^{2}
\end{gathered}=\begin{gathered}
\text { Percentage of diseased } \\
\text { plants } / \mathrm{m}^{2}
\end{gathered} \times \begin{gathered}
\text { Percentage of leaves } \\
\text { damaged/diseased plant }
\end{gathered}
$$

Two visual estimates were also used to determine the percentage of weed infestation in each plot at the end of the long and short-day seasons. Average selection values were developed from the percentages of leaves damaged by disease and from the visually estimated weed infestation. The following scale was used: poor -1.5 to 2.5 ; fair -2.5 to 3.5 ; good 3.5 to 4.5 ; excellent -4.5 to 5 .

At the end of the first year of evaluation each plot was examined for insect damage during a severe worm invasion in the experimental area. The following visual scale was used for this determination (13): null -1 
to 1.5 ; slight -1.5 to 2.5 ; moderate -2.5 to 3.5 ; and severe -3.5 to 4.0 . To estimate the percentage of truly digestible dry matter IVTD we used the methods of Goering and van Soest (3) and the additive equation of Arroyo-Aguilú and Coward-Lord (1), as follows: IVTD $=96.86+.62$ $(\% \mathrm{CP})-.51(\% \mathrm{C})-2.59(\% \mathrm{~L})-2.34(\mathrm{Si})$, where \% CP = percentage crude protein, $\% \mathrm{C}=$ percentage cellulose, $\% \mathrm{~L}=$ percentage lignin and $\% \mathrm{Si}=$ percentage silica.

Analyses of variance and Duncan's Multiple Range Test were used for data on annual, short-day and long-day season, dry matter yields and average selection values relating to insect, disease and weed infestation resistance.

\section{RESULTS AND DISCUSSION}

Table I presents mean selection value ratings on the basis of disease (leaf damage) and insect damage of each of the 20 grasses during a very rainy period in the first 13 weeks of the evaluation. Helminthosporium, Nigrospora, Colletotrichum and Puccinia were identified as pathogens. The eight $H$. altissima, $C$. nlemfuensis PRPI 2341 and $C$. plectostachyus PRPI 12949 showed the highest selection values based on disease tolerance. Table 1 also presents this information.

Leaf damage during a worm invasion at the end of 1988 was evaluated. All Cynodon cultivars suffered severe to moderate insect damage, and thus wrere judged to be more susceptible than all the Hemarthria cultivars. Six out of eight Hemarthria cultivars (cvs. $15,16,17,18,19$ and 20) presented slight to no damage, and only two (cv. 11 and 14) presented moderate damage.

Table 2 shows the mean weed infestation and selection values during the short- and long-day seasons. All cultivars with the exception of $H$. altissima PRPI 13207 and USDAPI 364873 increased in weed infestation percentages and decreased in selection value from the short- to the longday season. Evidently, the selection criteria used during the season of long days permitted a more reliable estimation of weed tolerance. Only seven Hemarthria cultivars showed excellent selection values (cvs. $14,15,16,17,18,19$ and 20), whereas one Hemarthria and one Cynodon showed good selection values (cvs. 11 and 7) for the long day season. These nine cultivars were chosen as the best materials, especially $H$. altissima PRPI 13202 and USDAPI 364873 and 379618, which presented the highest selection values for weed tolerance. The results are in agreement with those of Vélez-Santiago et al. (14) in which C. plectostachyus PRPI 11487 was among the highest weed resistant cultivars. However, the results differed in cultivars $C$. dactylon PRPI $11504 C$. plectostachyus PRPI 11486 and $C$. nlemfuensis PRPI 2341, which, according to Vélez-Santiago et al. (14), were among the most weed resistant cultivars.

Figure 1 shows plant height $(\mathrm{cm})$ estimates of the best adapted cul- 
TABLE 1.-Mean selection value rating on the basis of disease and insect damage

\begin{tabular}{|c|c|c|c|c|c|}
\hline \multirow[b]{2}{*}{ Number } & \multirow[b]{2}{*}{ Name } & \multirow[b]{2}{*}{ P.R.P.I. } & \multirow[b]{2}{*}{ U.S.D.A.P. I. } & \multicolumn{2}{|c|}{ Mean selection value } \\
\hline & & & & $\begin{array}{l}\text { Leaf damage' } \\
\text { due to disease }\end{array}$ & Insect damage ${ }^{2}$ \\
\hline 1 & C. plectostachyus & 11486 & 341817 & $3.57 \mathrm{~cd}$ & 2.94 bcde \\
\hline 2 & C. plectostachyus & 12949 & FL 4750 & $4.99 \mathrm{a}$ & $3.96 \mathrm{a}$ \\
\hline 3 & C. plectostachyus & 13396 & 409745 & $4.07 \mathrm{bc}$ & 3.18 abcde \\
\hline 4 & C. plectostachyus & 13397 & 409746 & 2.82 de & $3.65 \mathrm{ab}$ \\
\hline 5 & C. plectostachyus & 13398 & 409747 & $4.13 b c$ & 3.07 abcde \\
\hline 6 & C. plectostachyus & 13401 & 409750 & $3.57 \mathrm{~cd}$ & $3.43 \mathrm{abc}$ \\
\hline 7 & C. plectostachyus & 11487 & 341818 & 2.22 ef & 3.11 abcde \\
\hline 8 & C. plectostachyus & 13399 & 409748 & $3.47 \mathrm{~cd}$ & $3.86 \mathrm{a}$ \\
\hline 9 & C. plectostachyus & - & 409743 & $3.22 \mathrm{~d}$ & $3.36 \mathrm{abcd}$ \\
\hline 10 & C. dactylon & 1330 & - & $1.74 \mathrm{f}$ & $3.72 \mathrm{ab}$ \\
\hline 11 & H. altissima & 13198 & 364875 & $4.99 \mathrm{a}$ & 2.72 cdef \\
\hline 12 & C. nlemfuensis & 2341 & - & $4.88 \mathrm{a}$ & 3.32 abcd \\
\hline 13 & C. dactylon & 11504 & 255455 & $2.82 \mathrm{de}$ & $3.40 \mathrm{abc}$ \\
\hline 14 & H. altissima & - & 379617 & $5.14 \mathrm{a}$ & 2.57 cdef \\
\hline 15 & $H$. altissima & - & 364888 & $4.99 \mathrm{a}$ & $2.47 \mathrm{defg}$ \\
\hline 16 & H. altissima & 13395 & 409744 & $5.07 \mathrm{a}$ & $1.94 \mathrm{fgh}$ \\
\hline 17 & H. altissima & - & 364873 & $4.82 \mathrm{ab}$ & $1.65 \mathrm{gh}$ \\
\hline 18 & H. altissima & 13178 & 347238 & $4.97 \mathrm{a}$ & $2.36 \mathrm{efg}$ \\
\hline 19 & H. altissima & 13207 & 364889 & $5.14 \mathrm{a}$ & $1.32 \mathrm{~h}$ \\
\hline 20 & H. altissima & 13202 & 364881 & $4.82 \mathrm{ab}$ & $2.40 \mathrm{efg}$ \\
\hline
\end{tabular}

'Selection value rating - 4.5 to 5.0 - excellent; 3.5 to 4.5 - good; 2.5 to 3.5 - fair; 1.5 to 2.5 - poor.

'Selection value rating-3.5 to 4.0 - severe; 2.5 to 3.5 - moderate; 1.5 to 2.5 - slight; under 1.5 - null. 
TABLE 2.-Average weed infestation percentage and selection values during the short and long-day seasons of $1987-88$

\begin{tabular}{|c|c|c|c|c|c|}
\hline $\begin{array}{l}\text { Grass } \\
\text { number }\end{array}$ & $\begin{array}{c}\text { Average } \\
\text { infestation } \\
\%\end{array}$ & $\begin{array}{l}\text { Average } \\
\text { selection } \\
\text { value }\end{array}$ & $\begin{array}{l}\text { Grass } \\
\text { number }\end{array}$ & $\begin{array}{c}\text { Average weed } \\
\text { infestation } \\
\%\end{array}$ & $\begin{array}{l}\text { Average } \\
\text { selection } \\
\text { value }\end{array}$ \\
\hline \multicolumn{3}{|c|}{ Short-day season. } & \multicolumn{3}{|c|}{ Long-day season } \\
\hline 18 & 4 & $5.12 \mathrm{a}$ & 14 & 8 & $4.96 \mathrm{a}$ \\
\hline 17 & 9 & $5.11 \mathrm{a}$ & 20 & 8 & $4.96 \mathrm{a}$ \\
\hline 20 & 5 & $5.11 \mathrm{a}$ & 17 & 9 & $4.96 \mathrm{a}$ \\
\hline 16 & 11 & $5.05 a$ & 16 & 15 & $4.95 \mathrm{a}$ \\
\hline 14 & 4 & $4.90 \mathrm{a}$ & 19 & 14 & $4.71 \mathrm{a}$ \\
\hline 10 & 16 & $4.81 \mathrm{ab}$ & 18 & 19 & $4.70 a$ \\
\hline 11 & 9 & $4.81 \mathrm{ab}$ & 15 & 14 & $4.67 \mathrm{a}$ \\
\hline 15 & 10 & $4.81 \mathrm{ab}$ & 11 & 25 & $4.17 \mathrm{ab}$ \\
\hline 19 & 17 & $4.65 \mathrm{ab}$ & $?$ & 41 & $3.70 \mathrm{abc}$ \\
\hline 9 & 24 & $4.62 \mathrm{ab}$ & 9 & 41 & $3.45 b c$ \\
\hline 1 & 23 & $4.55 \mathrm{ab}$ & 10 & 49 & $3.17 \mathrm{bed}$ \\
\hline 7 & 34 & $4.12 \mathrm{abc}$ & 13 & 49 & $2.96 \mathrm{~cd}$ \\
\hline 13 & 34 & $4.11 \mathrm{abc}$ & 1 & 57 & 2.70 cde \\
\hline 5 & 30 & $3.65 \mathrm{bed}$ & 8 & 74 & $2.20 \mathrm{def}$ \\
\hline 12 & 32 & $3.65 \mathrm{bcd}$ & 4 & 71 & $1.96 \mathrm{def}$ \\
\hline 8 & 44 & $3.37 \mathrm{~cd}$ & 5 & 79 & $1.71 \mathrm{ef}$ \\
\hline 4 & 47 & $3.11 \mathrm{~cd}$ & 12 & 81 & $1.46 \mathrm{f}$ \\
\hline 6 & 45 & $3.05 \mathrm{~cd}$ & 2 & 80 & $1.42 \mathrm{f}$ \\
\hline 2 & 47 & $2.81 \mathrm{~d}$ & 3 & 87 & $1.20 \mathrm{f}$ \\
\hline 3 & 47 & $2.80 \mathrm{~d}$ & 6 & 90 & $1.20 \mathrm{f}$ \\
\hline
\end{tabular}

'Selection value rating- 4.5 to 4 - excellent; 3.5 to 4.5 - good; 2.5 to 3.5 - fair; 1.0 to 2.5 - poor.

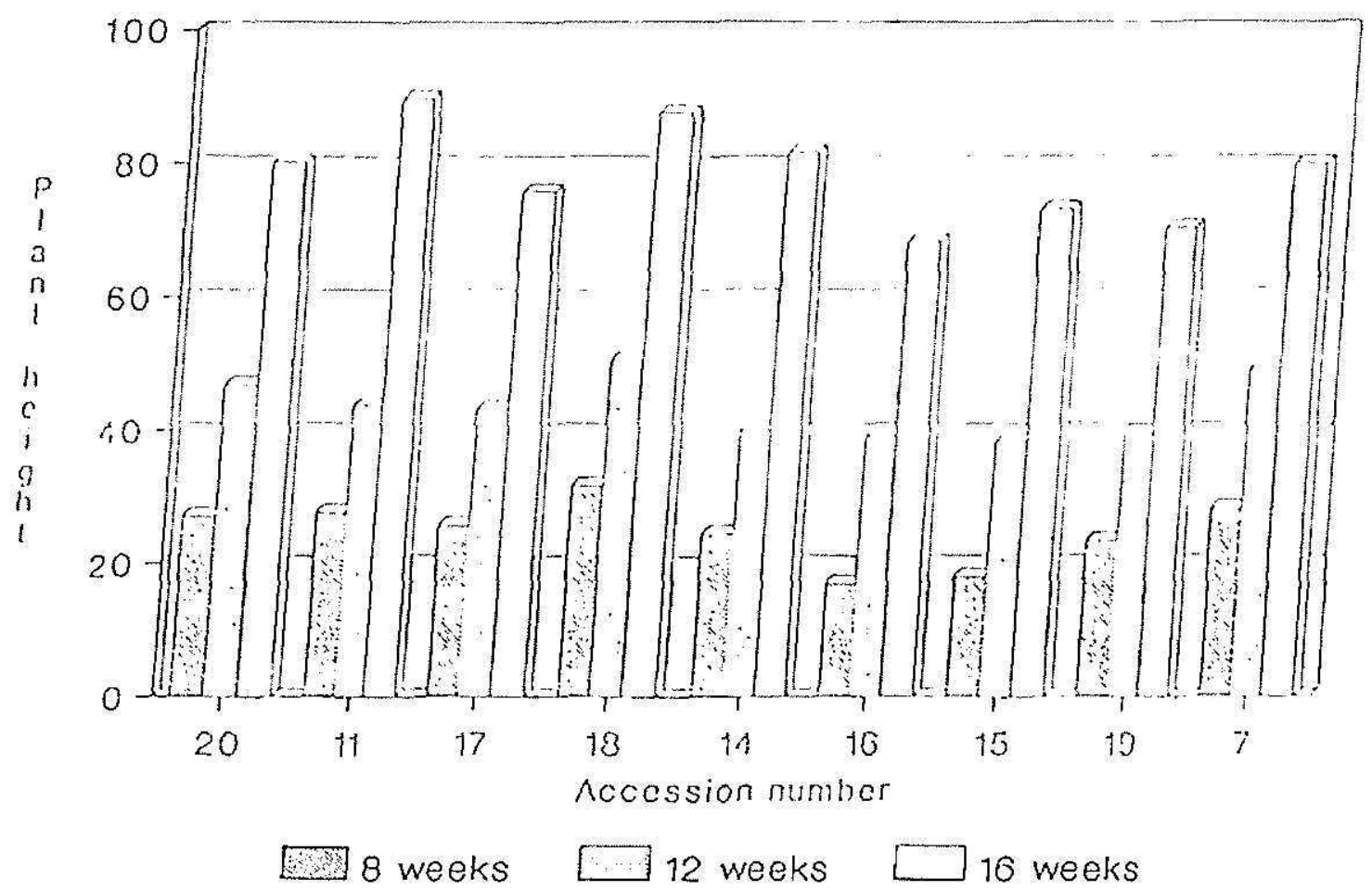

FIG. 1.-Plant height of selected accessions at three growing intervals during the establishment period. 
tivars after three growing intervals during the evaluation period. Data on plant height show that $C$. plectostachyus PRPI 11487 and $H$. altissima PRPI 13202, 13178 and 13198 and USDAPI 379617 were the highest at 12 and 16 weeks of growth. H. altissima PRPI, 13202, 13198 and 13207 and USDAPI, 364873 also showed the highest percentages of soil coverage after the three intervals (fig. 2). On the other hand, the lowest percentage of soil coverture on $H$. altissima USDAPI 364888 and 409744 may be attributable to their inferior germination rates. Considering both development characteristics (soil cover and plant height), $H$. altissima PRPI 13202 and 13198, showed the best adaptive performances. H. altissima PRPI 13198 can be considered as somewhat less well adapted because of its lower weed tolerance (table 2).

Table 3 shows data on mean dry matter yields $(\mathrm{kg} / \mathrm{ha})$ of the best adapted cultivars during short and long-day seasons and over the full year. H. altissima PRPI 13202, 13198 and 13178 and USDAPI 379617 and 364873 did not differ significantly in yield $(P=.05)$ during the two seasons. The same situation occurred with respect to yearly total dry matter yield, with the exception of USDAPI 379617, which was significantly $(\mathrm{P}=.05)$ lower than the others of this group. The remaining four of the nine best adapted cultivars (grasses no. 16,15,17 and 7). were significantly inferior $(P=.05)$ in terms of their dry matter yield.

Table 4 shows the IVTD of the best adapted cultivars according to the prediction equation of Arroyo-Aguilú and Coward-Lord (1) for trop-

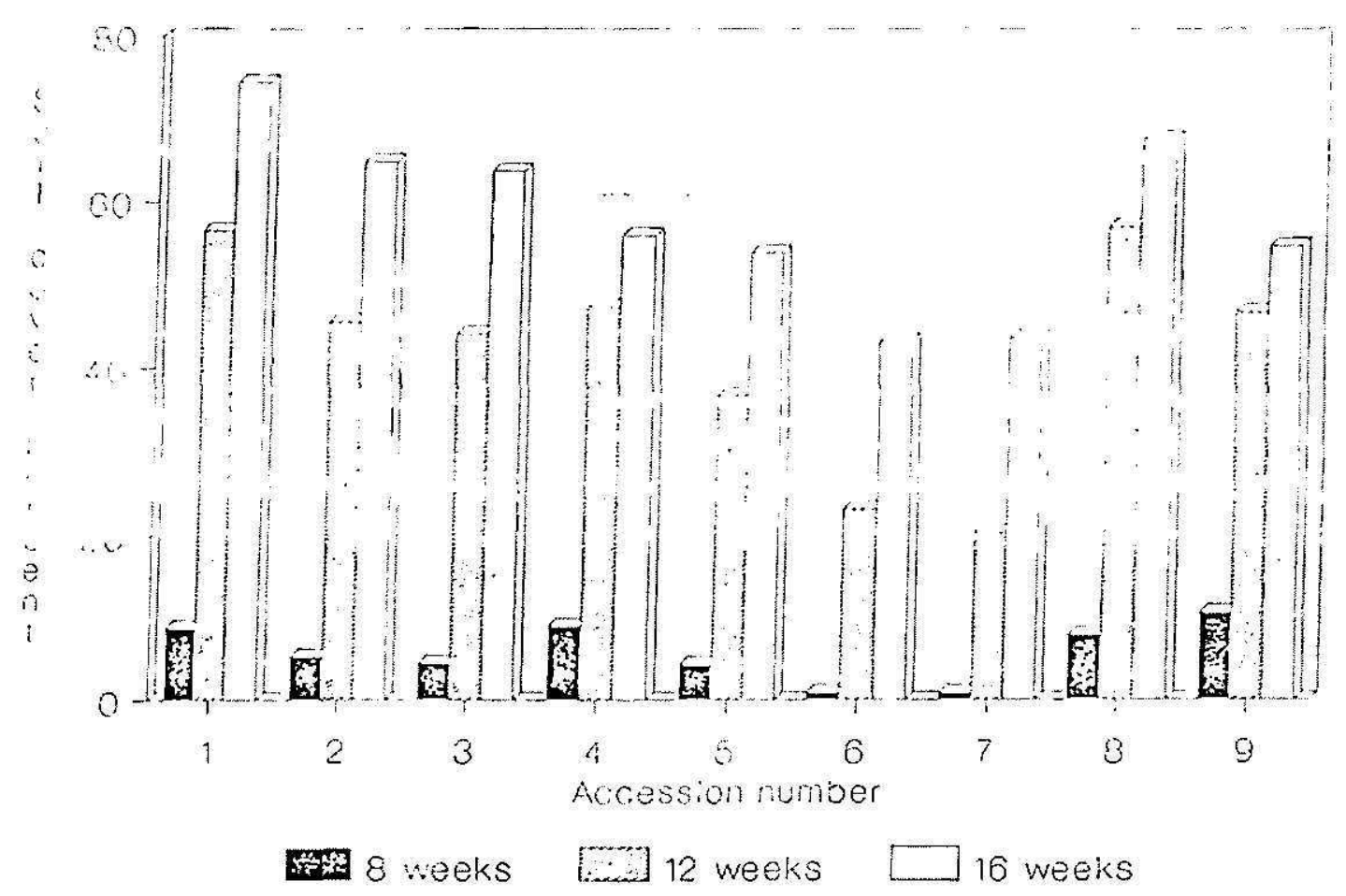

Frc. 2.-Soil covering ability of selected accessions at three growing intervals during the establishment period. 
TABLE 3.-Mean dry matter yields of adapted cultivars during the short and long-day seasons and the full year 1987-88

\begin{tabular}{cccc}
\hline $\begin{array}{c}\text { Grass } \\
\text { number }\end{array}$ & $\begin{array}{c}\text { Dry matter yield' } \\
(\mathrm{kg} / \mathrm{ha})\end{array}$ & $\begin{array}{c}\text { Dry matter yield } \\
(\mathrm{kg} / \mathrm{ha})\end{array}$ & $\begin{array}{c}\text { Dry matter yield } \\
(\mathrm{kg} / \mathrm{ha})\end{array}$ \\
\hline & Short-day season & Long-day season & Yeurly total \\
20 & $8,233 \mathrm{a}$ & $5,548 \mathrm{a}$ & $13,781 \mathrm{a}$ \\
11 & $7,865 \mathrm{ab}$ & $5,192 \mathrm{ab}$ & $13,057 \mathrm{ab}$ \\
17 & $7,703 \mathrm{abc}$ & $4,356 \mathrm{abc}$ & $12,059 \mathrm{abc}$ \\
18 & $7,232 \mathrm{abc}$ & $4,294 \mathrm{abc}$ & $11,526 \mathrm{abc}$ \\
14 & $6,921 \mathrm{abc}$ & $4,320 \mathrm{abc}$ & $11,241 \mathrm{bc}$ \\
16 & $6,723 \mathrm{bc}$ & $3,772 \mathrm{bc}$ & $10,495 \mathrm{~cd}$ \\
15 & $6,322 \mathrm{c}$ & $4,084 \mathrm{abc}$ & $10,406 \mathrm{~cd}$ \\
19 & $6,332 \mathrm{c}$ & $3,376 \mathrm{bc}$ & $9,708 \mathrm{~cd}$ \\
7 & $4,681 \mathrm{~d}$ & $3,810 \mathrm{bc}$ & $8,491 \mathrm{~d}$ \\
\hline
\end{tabular}

' Harvest interval every 28 days.

${ }^{2}$ Harvest interval every 21 days.

ical grasses. The IVTD estimates for the short-day season and over the full year were very similar for all nine cultivars. However, during the season of long days, cultivar C. plectostachyus PRPI 11487 appeared to be inferior in terms of digestibility whereas $H$. altissima PRPI 13207 was superior among all cultivars.

The use of the simulated grazing technique in combination with agronomic evaluation allowed screening and selection of the best adapted cultivars in a short time. Four of the 20 grasses under evaluation excelled in adaptive performance and demonstrated that this technique was efficient when used during evaluations under the cutting system. However, exposure of these same experimental plots to the effects of grazing animals for at least another year is necessary for evaluating additional important performance criteria.

TABLE 4.-In vitro tme digestibility (IVTD) of the best adapted cultivars according to the prediction equation of Arroyo-Aguilu and Coward-Lord (1)

\begin{tabular}{cccc}
\hline $\begin{array}{c}\text { Grass } \\
\text { number }\end{array}$ & $\begin{array}{c}\text { IVTD } \\
\text { Short days }\end{array}$ & $\begin{array}{c}\text { IVTD } \\
\text { Long days }\end{array}$ & $\begin{array}{c}\text { Average } \\
\text { IVTD } \\
\text { for the year }\end{array}$ \\
\hline 7 & 58.2 & 53.0 & 55.6 \\
11 & 58.2 & 58.2 & 58.2 \\
14 & 57.5 & 56.2 & 56.8 \\
15 & 60.0 & 55.3 & 57.6 \\
16 & 56.5 & 56.6 & 56.5 \\
17 & 57.9 & 57.8 & 57.8 \\
18 & 56.2 & 57.0 & 56.6 \\
19 & 57.9 & 60.0 & 58.9 \\
20 & 58.4 & 55.9 & 57.1 \\
\hline
\end{tabular}




\section{LITERATURE CITED}

1. Arroyo-Aguilti, J. A. and J. Coward Lord, 1974. Relationships between and within physical and chemical constituents and in vitro true digestibility in tropical forage grasses. J. Agric. Univ. P. R. 25 (4): 437-46.

2. Gardner, A. L., 1983. Evaluación por corte y por pastoreo en pequeñas parcelas: comparación de resultados. Germoplasma forrajero bajo pastoreo en pequeñas parcelas. Metodologia de evaluación, Memorias de una Reunión de Trabajo, Cali, Colombia, sept. 22-24, 1982, RIEPT, CIAT, p. 107. Editadas por Osvaldo Paladines y Carlos Lascano.

3. Goering, H. K., and P. G. van Soest, 1970. Forage fiber analyses aparatus, reagents procedures and some applications. USDA Agric. Handb., p. 379.

4. Grob, B., 1983. Selección de cultivares forrajeros partiendo de muchas entradas sometidas a pastoreo. Germoplasma forrajero bajo pastoreo en pequeñas parcelas. Metodología de evaluación, Memorias de una Reunión de Trabajo, Cali, Colombia, sept. 22-24, 1982, RIEPT, CIAT, p. 122-23. Editadas por Osvaldo Paladines y Carlos Lascano.

5. Mott, G. O., 1983. Evaluación del germoplasma forrajero bajo pastoreo en pequeñas parcelas. Metodología de evaluación, Memorias de una Reunión de Trabajo, Cali, Colombia, sept. 22-24, 1982, RIEPT, CIAT, p. 149-150. Editadas por Osvaldo Paladines y Carlos Lascano.

6. Paladines, O. y C. Lascano, 1983. Recomendaciones para evaluar germoplasma bajo pastoreo en pequeñas parcelas. Germoplasma forrajero bajo pastoreo en pequeñas parcelas. Metodologia de evaluación, Memorias de una Reunión de Trabajo, Cali, Colombia, sept. 22-24, 1982, RIEPT, CIAT, p. 168. Editadas por Osvaldo Paladines y Carlos Lascano.

7. Quesenberry, K.H., L. S. Duanin, Jr., E. M. Hodges, C. B. Villinger, A. E. Kretschner Jr., W. R. Ocupaugh, R. D. Rouseh, O. C. Ruelke, S. C. Shank, D. C. Smith, G. H. Snyder and R. L. Stanley, 1978. Redalta, Greenalta and Bigalta, limpograss, Hemarthria altissima, promising forages for Florida. FI. Agric. Exp. Stn., Institute of Food and Agricultural Sciences; Gainesville. Bull. 802.

8. Rodríguez, J. and E. Rivera, 1980. Forage yield of five grasses under intensive grazing: management in the humid region of Puerto Rico. J. Agric. Univ. P. R. 64 (3): 259-63.

9. Rodriguez, J. and S. Silva, 1975. Effect of two heights and three intervals of gxazing on stand of a heavily fertilized star grass pasture. J. Agric. Univ. P. R. 59 (3): 215-18.

10. Shank, S. C., M. A. Klock and J. E. Moore, 1973. Laboratory evaluation of quality in subtropical grasses: 1I. Genetic variation among Hemarthrias in in vitro digestion and stem morphology. Agron. J. 65: 256-58.

11. Sotomayor-Ríos, A., F. J. Juliá and J. A. Arroyo-Aguilú, 1974. Effects of harvest interval on the yield and composition of 10 forage grasses. J. Agric. Univ. P. R. 58: (4): $448-55$.

12. Tergas, L. E., J. Vélez-Santiago and D. Vera de Saldaña, 1986. Response of tropical grasses to potassium fertilization in the humid coastal region of Puerto Rico. $J$. Agric. Lniv. P. R. 72 (1): 81.

13. Toledo, J. M., 1982. Manual para la evaluación agronómica, red internacional de evaluación de pastos tropicales. Centro Internacional de Evaluación de Pastos Tropicales. Centro Internacional de Agricultura Tropical (CIAT) p. 91-110.

14. Vélez-Santiago, J., A. Sotomayor-Ríos and S. Torres-Rivera, 1979. Effect of three harvest intervals and two fertilizer rates on the yield and HCN content of ten Cynodon cultivars. J. Agric. Univ. P. R. 63 (1): 35-44.

15. — and — 1983. Nitrogen fertilization and cutting frequency yield and chemical composition of five tropical grasses. J. Agric. Univ. P. R. 67 (2):61-9. 
16. Vicente-Chandler, J., J. Rodríguez and F. Abruña, 1972. Effects of two heights and three intervals of grazing on the productivity of heavily fertilized Pangola grass pasture, J. Agric. Univ. P. R. 56 (2): 110-14. 